\title{
Knowledge, Attitudes and Practices of Infertile Women on Child Adoption in Douala (Cameroon)
}

\author{
Charlotte Tchente Nguefack ${ }^{1,2 *}$, Clovis Ourtching ${ }^{1}$, Halle Ekane Gregory ${ }^{1,3}$, \\ Eugène Belley Priso ${ }^{1,4}$ \\ ${ }^{1}$ Obstetrics and Gynecology Unit, Douala General Hospital, Douala, Cameroon \\ ${ }^{2}$ Department of Obstetrics and Gynecology, Faculty of Medicine and Pharmaceutics Science, University of \\ Douala, Douala, Cameroon \\ ${ }^{3}$ Department of Obstetrics and Gynecology, Faculty of Health Sciences, University of Buea, Buea, Cameroon \\ ${ }^{4}$ Department of Obstetrics and Gynecology, Faculty of Medicine and Biomedical Science, University of \\ Yaoundé, Yaoundé, Cameroon \\ Email: ${ }^{*}$ cnguefack2007@yahoo.fr
}

Received 26 September 2014; revised 25 October 2014; accepted 18 November 2014

Academic Editor: Yasam Kemal Akpak, Ankara Mevki Military Hospital, Turkey

Copyright (C) 2014 by authors and Scientific Research Publishing Inc.

This work is licensed under the Creative Commons Attribution International License (CC BY).

http://creativecommons.org/licenses/by/4.0/

(c) (i) Open Access

\begin{abstract}
Background: The aim of the study was to evaluate the knowledge, attitude and practices on child adoption among infertile women in Douala (Cameroon). Methods: It was a prospective descriptive study of six months duration at the General Hospital and the Dawn Medical Foundation Clinic. Patients of the gynecologic unit presenting with infertility were included. A questioner was administer to each patient with the following variables: Age, marital status, profession, level of education, past gynecologic history, number of children, type and the duration of infertility. Their knowledge, attitude and practice toward child adoption were investigated. Data collected was analyzed using the statistical software EPI-INFO 6.04 and R. p value $<0.05$ was considered to be statistically significant. Results: Among the 300 women included, 269 (89.7\%) had already heard about adoption, $62.1 \%$ through the media. Seventeen percent knew who to meet in order to adopt a child in Cameroon. Two hundred and thirty patients (76.7\%) were in favor of adoption but $48.7 \%$ of them didn't want to adopt a child. One percent of patient had adopted a child. The attitude towards adoption was significantly influenced by the duration of infertility of more than 10 years (p = 0.0014). Among women who have at least one child $9.4 \%$ wanted adoption against $21.4 \%$ who did not want adoption ( $p=0.0305)$. Among women aged between 25 and 30 years, $28.2 \%$ wanted to adopt a child against $79.1 \%$ who did not want it $(p=0.000)$. Eighty five percent of women who had secondary infertility did not want to adopt against $44.7 \%$ who wanted it $(p=0.0003)$. Conclusion:
\end{abstract}

\footnotetext{
${ }^{*}$ Corresponding author.
}

How to cite this paper: Nguefack, C.T., et al. (2014) Knowledge, Attitudes and Practices of Infertile Women on Child Adoption in Douala (Cameroon). Open Journal of Obstetrics and Gynecology, 4, 1065-1071.

http://dx.doi.org/10.4236/ojog.2014.416146 
The level of knowledge is high in educated patient. However, many women don't know the right procedure and the structures in charge of adoption. Their attitude is favorable but the practice of adoption remains low.

Keywords

Knowledge, Attitudes, Practices, Child's Adoption, Douala

\section{Introduction}

Infertility is the inability of a couple to have a child after one year of regular sexual intercourse. Its prevalence is $15 \%$ to $20 \%$ worldwide [1]-[3]. For half of the women and $15 \%$ of the men interviewed, infertility is one of the most disturbing challenges in life [4]. Actually, in our societies, the absence of a desired pregnancy rapidly becomes the source of intense frustration and early consultation to a physician. One in 7 couples will consult a physician at least once for suspicion of infertility whereas one couple in 10 will consult for treatment of infertility [5]. The needs of couples and the therapeutic options have been increasing with time. Solutions range from medical treatment to techniques of assisted reproductive technology. A study done in France showed that in 100 couples requesting assisted reproductive technology (ART), 20 have a child with the first attempt of In vitro Fertilization (IVF), 40 during the fourth IVF. For the 40 couples who are not able to have children through ART, 20 will never had children, 20 will eventually have children, 10 naturally and 10 by adoption [6].

Adoption is a legal act where a child becomes affiliated to a parent to whom he/she is not biologically related. This practice is well known and done in certain high income countries practice, whereas only $1.2 \%$ of couples had already adopted a child, $27.2 \%$ had the desire to adopt a child [7]. The acceptance of adoption does not depend only on the level of education but also on the socio-economic level [8] [9]. In addition, social beliefs constitute a non-negligible influence on attitude towards adoption [10] [11]. In our milieu, where the socio-economic level does not permit many couples to have access to ART, how then does the patient regard child adoption?

\section{Methods}

We did a cross sectional study from $1^{\text {st }}$ June to $30^{\text {th }}$ November 2012. Outpatients and inpatients with infertility consulting at the gynecological unit of Douala General Hospital and Down Medical Foundation clinic were recruited: Douala general hospital is a tertiary level hospital (the reference hospital in our system). The Down Medical Foundation clinic is a secondary level structure. The number of consultation in 2012 at the clinic and the hospital were respectively 2880 and 59,199 with 6439 in the obstetrics and Gynecology Unit. Infertility has been defined as the absence of pregnancy after regular sexual intercourse (3 days/week averagely) for 1 year. We obtained ethics clearance from hospitals. Patients with infertility who did not give their consent to participate in the study were excluded. After some explanation on the aim of the study and the obtention of their informed consent, we filled a pretested questionnaire. Patients were enrolled consecutively. Variables studied included age, marital status, profession, level of education, ethnicity and religion. The past gynecological and obstetrical history of participants, the type and duration of infertility were documented. Their level of knowledge and their attitude towards adoption was evaluated, and the practice of child adoption was investigated. The sample size was calculated using Lorentz formula

$$
n=\frac{t^{2} \times p(1-p)}{\mathrm{e}^{2}}
$$

$n=$ sample size

$t=$ level of confidence deduced from the confidence rate (traditionally 1.96 for a 95\% confidence interval)— measure of central tendency

$p=$ prevalence, $p=20 \%$ (prevalence of infertility) [1]

$\mathrm{e}=$ margin of error (traditionally fixed at $5 \%$ )

this lead to a sample size of 245 participants. 
The data collected was analyzed with the statistical software EPI-INFO 6.04 and R. The chi-square test was used for comparisons of values with a p value less than 0.05 considered statistically significant.

\section{Results}

\subsection{Study Population}

A total of 300 infertile patients were recruited in this study. 326 patients were invited and 300 gave inform consent. The response rate was $92.02 \%$. The most represented age range was between 25 and 30 years (64.7\%). The majority of patients were Christians (95.7\%). Most of the patients were at least educated up to the level of secondary school (92.3\%). Primary infertility was found in $26.33 \%$ whereas secondary infertility was found in $73.7 \%$ (Table 1).

\subsection{Knowledge}

Two hundred and sixty nine patients (89.7\%) had already heard about adoption and among them $62.1 \%$ were informed via the media. Only $17.1 \%$ knew who to meet in order to adopt a child in Cameroon (Table 2). Edu-

Table 1. Socio-demographics characteristics of patients.

\begin{tabular}{|c|c|c|}
\hline Variables & \multicolumn{2}{|c|}{ Total $n=300(\%)$} \\
\hline \multicolumn{3}{|l|}{ Age (years) } \\
\hline$\leq 20$ & 1 & 0.3 \\
\hline $20-25$ & 24 & 8 \\
\hline $25-30$ & 194 & 64.7 \\
\hline $30-35$ & 44 & 14.7 \\
\hline $35-40$ & 30 & 10 \\
\hline$>40$ years & 7 & 2.3 \\
\hline \multicolumn{3}{|l|}{ Marital statuts } \\
\hline Married & 170 & 56.7 \\
\hline Single & 130 & 43.3 \\
\hline \multicolumn{3}{|l|}{ Profession } \\
\hline Private worker & 125 & 41.7 \\
\hline Civil servant & 77 & 25.7 \\
\hline Housewife & 62 & 20.7 \\
\hline Student & 36 & 12 \\
\hline \multicolumn{3}{|l|}{ Religion } \\
\hline Christian & 287 & 95.7 \\
\hline Muslim & 13 & 4.3 \\
\hline \multicolumn{3}{|l|}{ Educational level } \\
\hline Primary & 20 & 6.7 \\
\hline Secondary & 120 & 40.0 \\
\hline University & 157 & 52.3 \\
\hline Never been to school & 3 & 1.0 \\
\hline \multicolumn{3}{|l|}{ Infertility type } \\
\hline Primary infertility ${ }^{*}$ & 79 & 26.3 \\
\hline Secondary infertility ${ }^{*}$ & 221 & 73.7 \\
\hline
\end{tabular}

a) Primary infertility ${ }^{*}$ : When a woman is unable to ever bear a child, either due to the inability to become pregnant or the inability to carry a pregnancy to a live birth; b) Secondary infertility ${ }^{*}$ : When a woman is unable to bear a child, either due to the inability to become pregnant or the inability to carry a pregnancy to a live birth following either a previous pregnancy or a previous ability to carry a pregnancy to a live birth. 
Table 2. Knowledge on child adoption.

\begin{tabular}{|c|c|c|c|c|c|c|}
\hline Variables & \multicolumn{2}{|c|}{ Yes $n=269(\%)$} & \multicolumn{2}{|c|}{ No $n=31(\%)$} & \multicolumn{2}{|c|}{ Total $n=300(\%)$} \\
\hline Know that we can adopt & 228 & 84.8 & / & & 228 & 76.0 \\
\hline Don’t know & 41 & 15.2 & 31 & 100 & 72 & 24.0 \\
\hline \multicolumn{7}{|l|}{ Source of information } \\
\hline Media & 167 & 62.1 & / & & 167 & 55.7 \\
\hline Hospital & 16 & 5.9 & l & & 16 & 5.3 \\
\hline Parent & 26 & 9.7 & / & & 26 & 8.7 \\
\hline Friend & 60 & 22.3 & I & & 20 & 6.7 \\
\hline \multicolumn{7}{|l|}{ Procedure } \\
\hline Known & 163 & 60.6 & I & & 163 & 54.3 \\
\hline Unknown & 106 & 39.4 & 31 & 100 & 137 & 45.7 \\
\hline \multicolumn{7}{|l|}{ Structures in charge } \\
\hline Know the structures & 46 & 17.1 & / & & 46 & 15.3 \\
\hline Don’t know & 223 & 82.9 & 31 & 100 & 254 & 84.7 \\
\hline
\end{tabular}

cated patients had heard more about adoption (55.8\%), they knew more about adoption of children in Cameroon (48.3\%), that a procedure existed (33.5\%) and the structure concerned (9.3\%) (Table 3).

\subsection{Attitudes}

Two hundred and thirty patients (76.7\%) were in favor of adoption but $48.7 \%$, despite being in favor did not want to adopt a child (Table 4). The attitude towards adoption was significantly influenced by the duration of infertility: $44.7 \%$ of women who had infertility for more than 10 years wanted to adopt a child versus $14.4 \%$ who did not want to adopt $(\mathrm{p}=0.0014)$. Among women who have at least one child $9.4 \%$ wanted adoption against $21.4 \%$ who did not want adoption $(\mathrm{p}=0.0305)$. Among women aged between 25 and 30 years, 28.2\% wanted to adopt a child against $79.1 \%$ who did not want it $(\mathrm{p}=0.000)$. $85.1 \%$ of women who had secondary infertility did not want to adopt against $44.7 \%$ who wanted it $(\mathrm{p}=0.0003)$ (Table 5$)$.

\subsection{Practice}

One percent of patients had already adopted a child. Their motivation was the long duration of infertility (66.7\%) and the ardent desire to have a child (33.3\%) (Table 6).

\section{Discussion}

Among the 300 patients recruited, 89.7\% had heart about adoption, mainly through media. Although 76.7\% were in favor of adoption, only $1 \%$ had already adopted a child.

Nwobodo et al. [7] found that $74.8 \%$ of participants had knowledge on the subject of adoption whereas Ezugwu et al. [9] found $86.4 \%$, with $27.3 \%$ who knew exactly the meaning of adoption. This is concordant with our findings (89.7\%). Adewunmi et al. found that $47.8 \%$ of participants who had information on the subject obtained it from friends, which is contrary to our findings, where the majority $62.1 \%$ obtained information from the media. Avidime et al. also found that the media constituted the main source of information in $35 \%$. We think that our study follows the "phenomenon of stolen baby at the Gynaecologic Obstetric and Pediatric Hospital of Yaounde" which was the subject of much talking on our radio and television channels with frequent mentioning of the topic of child adoption [12]. 
Table 3. Knowledge according to educational level.

\begin{tabular}{ccccccccccc}
\hline Variables & Total n \% & Analphabet n \% & \multicolumn{2}{c}{$\begin{array}{c}\text { Primary level } \\
\mathbf{n} \%\end{array}$} & $\begin{array}{c}\text { Secondary level } \\
\text { n \% }\end{array}$ & \multicolumn{2}{c}{ Superior n \% } \\
\hline Never heard about adoption & 31 & 10.3 & 3 & 9.7 & 8 & 25.8 & 13 & 41.9 & 7 & 22.6 \\
Have heard about adoption & 269 & 89.7 & 0 & 0.0 & 12 & 4.5 & 107 & 39.8 & 150 & 55.8 \\
Adoption is possible in Cameroon & 228 & 84.8 & 0 & 0.0 & 7 & 2.6 & 91 & 33.8 & 130 & 48.3 \\
Procedures well known & 162 & 60.2 & 0 & 0.0 & 5 & 1.8 & 67 & 24.9 & 91 & 33.8 \\
Structures in charge well known & 46 & 17.1 & 0 & 0.0 & 4 & 1.4 & 17 & 6.3 & 25 & 9.3 \\
\hline
\end{tabular}

Table 4. Attitudes towards child adoption.

\begin{tabular}{|c|c|c|c|c|c|}
\hline Variables & Favorable & $n=230(\%)$ & Non favorable $n=70$ & $(\%)$ & $\mathbf{p}$ \\
\hline \multicolumn{6}{|l|}{ Would like to adopt because } \\
\hline AMP is cost effective & 21 & 9.1 & 0 & 0.0 & 0.9999 \\
\hline Low success of AMP & 24 & 10.4 & 0 & 0.0 & 0.1505 \\
\hline It is easy & 39 & 17.1 & 1 & 1.4 & 0.0650 \\
\hline Total & 84 & 36.5 & 1 & 1.4 & \\
\hline \multicolumn{6}{|l|}{ Don't want to adopt because of } \\
\hline Stigmatisation & 45 & 19.6 & 29 & 41.4 & 0.1211 \\
\hline Complexity of the procedure & 16 & 7.1 & 12 & 17.1 & 0.5214 \\
\hline Child may not have consideration to his parent & 46 & 20.1 & 17 & 7.4 & 0.5822 \\
\hline cultural reasons & 39 & 17.1 & 11 & 15.7 & 0.9999 \\
\hline Total & 146 & 48.7 & 69 & 98.57 & \\
\hline
\end{tabular}

Table 5. Attitudes towards adoption according to the duration of infertility, number of children alive, maternal age and type of infertility.

\begin{tabular}{|c|c|c|c|c|c|}
\hline Caracteristics & \multicolumn{2}{|c|}{ Would like to adopt $n=85(\%)$} & \multicolumn{2}{|c|}{ Don't want to adopt $n=215(\%)$} & $\mathbf{p}$ \\
\hline 1 year & 2 & 2.4 & 21 & 9.8 & 0.2126 \\
\hline 2 - 5 years & 28 & 32.9 & 78 & 36.3 & 0.9822 \\
\hline 6 - 10 years & 17 & 20.1 & 85 & 39.5 & 0.0964 \\
\hline$>10$ years & 38 & 44.7 & 31 & 14.4 & 0.0014 \\
\hline \multicolumn{6}{|c|}{ Number of children } \\
\hline No children & 77 & 90.6 & 169 & 78.6 & 0.3559 \\
\hline >one child & 8 & 9.4 & 46 & 21.4 & 0.0305 \\
\hline \multicolumn{6}{|l|}{ Age } \\
\hline 18 - 24 years & 14 & 16.5 & 10 & 0.5 & 0.0024 \\
\hline 25 - 30 years & 24 & 28.2 & 170 & 79.1 & 0.0000 \\
\hline 31 - 39 years & 41 & 48.2 & 33 & 15.3 & 0.0013 \\
\hline$\geq 40$ years & 6 & 7.1 & 2 & 0.9 & 0.2083 \\
\hline \multicolumn{6}{|l|}{ Type of infertility } \\
\hline Primary & 47 & 55.3 & 32 & 14.9 & 0.0000 \\
\hline Secondary & 38 & 44.7 & 183 & 85.1 & 0.0003 \\
\hline
\end{tabular}


Table 6. Practices on child adoption.

\begin{tabular}{|c|c|c|c|c|}
\hline Caracteristics & \multicolumn{2}{|c|}{$\begin{array}{l}\text { Has adopt } \\
\mathrm{n}=3(\%)\end{array}$} & \multicolumn{2}{|c|}{$\begin{array}{l}\text { Never adopt } \\
\mathrm{n}=297(\%)\end{array}$} \\
\hline Ardent need of a child & 1 & 33.3 & & / \\
\hline Infertility of long duration & 2 & 66.7 & & I \\
\hline Simplicity of the procedure & 0 & 0.0 & & I \\
\hline \multicolumn{5}{|l|}{ Reasons for non adoption } \\
\hline No information & & I & 45 & 15.2 \\
\hline Complexity of the procedure & & / & 73 & 24.6 \\
\hline Cultural reasons & & / & 127 & 42.8 \\
\hline Hope of natural conception & & / & 52 & 17.5 \\
\hline
\end{tabular}

We found in our study that the level of education influences the knowledge on the adoption. The most educated people were those who knew that it was possible to adopt a child in Cameroon and knew structures to go to.

The attitude of participants towards adoption was good as 76.7\% was favorable. Avidime et al. [13] found that $77 \%$ had good attitudes towards adoption and that there was an association between the number of living children and the desire to adopt a child. Adewunmi et al. [8] found that $42.6 \%$ of the patients wanted the option of adoption only if there was no solution to the infertility. Olandokun et al. in a similar study done in Nigeria [10] found that $64 \%$ thought that adoption is culturally unacceptable. Whereas in the study done by Nwobodo et al. [7], 71.6\% of participants with infertility did not want to adopt because adoption of children did not permit them to fulfill their role of conception as women. The $23 \%$ of participants with infertility in our study who did not want adoption gave as reason stigmatization from their family and the factors related to tradition. Ezugwu et al. [9] found that $69.3 \%$ of patients did not want adoption for fear of abnormal behavior from the adopted child, the past history of his parents, and mainly because according to them adoption was not a solution to the problem of infertility. It stands out in many studies [7] [8] [14] like ours that duration of infertility of more than five years, advanced maternal age, absence of children strongly influence the decision in adopting a child.

The adoption rate remains low according to most researchers, ranging from $1.2 \%$ - 7.0\% [4] [9] [14]. It is 1.2\% according to Nwobodo et al. [4], 4.5\% according to Ezugwu et al. [9] and 7\% according to Ali and Sami [14]. The main decision maker in the study by Ali and Sami was the husband in $17 \%$ of the cases and the mother-inlaw in $68 \%$ of the cases. Oladokun et al. [8] in another older study in Nigeria found that obstacles to child adoption were the culture, the fear of stigmatization, financial problems and the complexity of the procedure. These findings were similar to ours with an adoption rate of $1.0 \%$. Among those who adopted a child, $66.7 \%$ did it because of long duration of infertility (more than 6 years). The reasons given by those who did not want adoption where cultural $42.8 \%$, complexity of the procedure $24.6 \%$ and the hope of conceiving by young women $17.5 \%$.

Limitations of the study concern the sample size and duration of the study which are not large. Furthermore, family incomes are not mentioned and there is no involvement of spouses.

\section{Conclusion}

The study of knowledge, attitudes and practices of infertile women towards child adoption presents several disparities. The level of knowledge remains high $89.7 \%$ especially in participants having a good level of education, the media being the best source of information at the moment of the study. However, a considerable number of women do not know the procedure or the structures responsible for adoption. The overall attitude remains favorable but only $1.0 \%$ of infertile women have already adopted a child. The reasons given by those who have not adopted children are mostly influenced by cultural beliefs. Considering the lack of awareness of adoption and the procedures involve, physicians and administrators should carry out IEC programs and simplify procedures to make this option available abate the sufferings of distressed couples who cannot have access to ART. 


\section{Conflicts of Interest}

None. The authors do not declare any conflict of interest.

\section{Contribution of Authors}

All authors contributed in the project conception, data collection and analysis, drafting and proof reading the manuscript.

\section{Acknowledgements}

Thanks to the Chief Medical Officer of "Dawn Medical Foundation” (Dr. Batupe Christopher) and all the paramedical staff for their help in recruiting patients.

\section{References}

[1] Spira, A. (1986) Epidemiology of Human Reproduction. Human Reproduction, 1, 111-115.

[2] Leridon, H. (1991) Sterility and Hypofertility: From Silence to Impatience? Population, 46, 227-248. http://dx.doi.org/10.2307/1533235

[3] De Mouzon, J., Spira, A. and Schwartz, D. (1988) A Prospective Study of the Relation between Smoking and Fertility. International Journal of Epidemiology, 17, 378-384.

[4] Delaisi de Parseval, G. (2008) Famille à tout prix. Seuil, Paris.

[5] Blanchy, S. (2011) L’adoption, alternative à l'assistance médicale à la procréation? Gynécologie Obstétrique \& Fertilité, 39, 491-495. http://dx.doi.org/10.1016/j.gyobfe.2010.10.014

[6] De la Rochebrochard, E. (2008) 200,000 enfants conçus par fécondation in vitro en France depuis 30 ans. Population \&Sociétés, 451.

[7] Nwobodo, E.I. and Isah, Y.A. (2011) Knowledge, Attitude and Practice of Child Adoption among Infertile Female Patients in Sokoto North-West Nigeria. The Nigerian Postgraduate Medical Journal, 18, 272-275.

[8] Adewunmi, A.A., Etti, E.A., Tayo, A.O., Rabiu, K.A., Akindele, R.A., Ottun. T.A. and Akinlusi, F.M. (2012) Factors Associated with Acceptability of Child Adoption as a Management Option for Infertility among Women in a Developing Country. International Journal of Women's Health, 4, 365-372. http://dx.doi.org/10.2147/IJWH.S31598

[9] Ezugwu, F.O., Obi, S.N. and Onah, H.E. (2002) The Knowledge, Attitude and Practice of Child Adoption among Infertile Nigerian Women. Journal of Obstetrics and Gynaecology, 22, 211-216. http://dx.doi.org/10.1080/01443610120113463

[10] Oladokun, A., Arulogun, O., Oladokun, R., Adenike Bello, F., Morhassan-Bello, I.O., Bambgoye, E.A., Adewole, I.F. and Ojengbede, O.A. (2010) Attitude of Infertile Women to Child Adoption in Nigeria. Niger J Physiol Sci., 25, 47-49.

[11] Oladokun, A., Arulogun, O., Oladokun, R., Morhason-Bello, I.O., Bamgboye, E.A., Adewole, I.F. and Ojengbede, O.A. (2009) Acceptability of Child Adoption as Management Option for Infertility in Nigeria: Evidence from Focus Group Discussions. African Journal of Reproductive Health, 13, 79-91.

[12] Médiatisation-Extension (2012) L’affaire Vanessa Tchatchou à la “Une” du débat africain. http://www.cameroon-info.net

[13] Avidime, S., Ameh, N., Adesiyun, A.G., Ozed-Williams, C., Isaac, N., Aliyu, Y., Sullyman, K., Idris, H. and Ojabo, A. (2013) Knowledge and Attitude towards Child Adoption among Women in Zaria, Northern Nigeria. Nigerian Medical Journal, 54, 261-264. http://dx.doi.org/10.4103/0300-1652.119657

[14] Ali, T.S. and Sami, N. (2007) Adoption Practices among Couples with Secondary Infertility in Karachi: A Triangulation Study Design. Journal Pakistan Medical Association, 57, 55-59. 
Scientific Research Publishing (SCIRP) is one of the largest Open Access journal publishers. It is currently publishing more than 200 open access, online, peer-reviewed journals covering a wide range of academic disciplines. SCIRP serves the worldwide academic communities and contributes to the progress and application of science with its publication.

Other selected journals from SCIRP are listed as below. Submit your manuscript to us via either submit@scirp.org or Online Submission Portal.
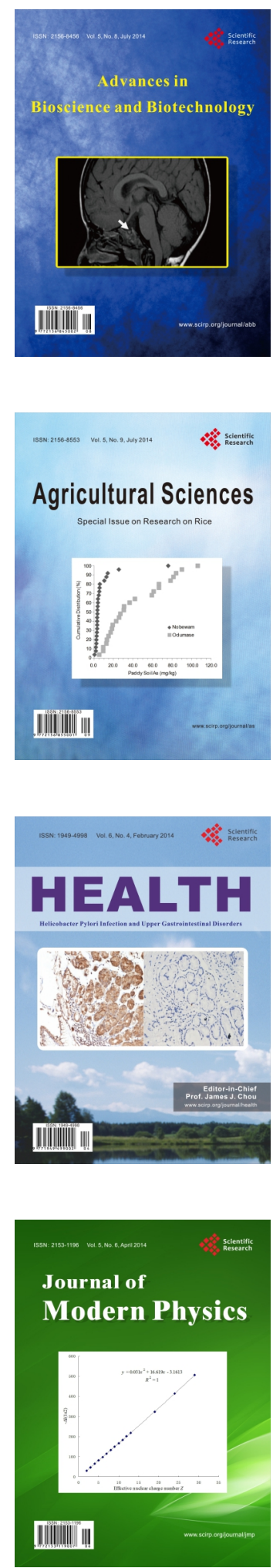
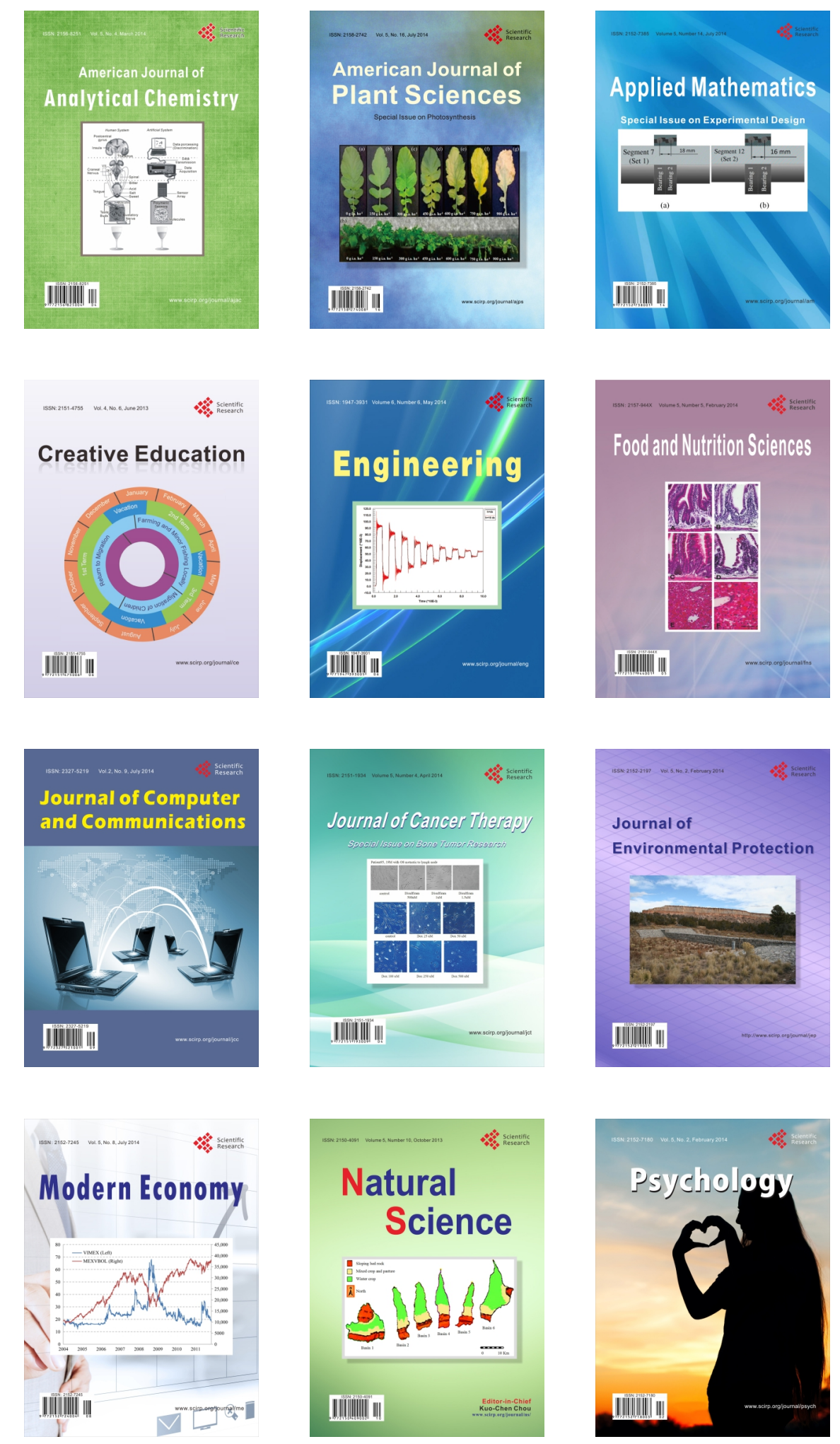